\title{
Eros and Ethics in Martin A. Hansen's Novel The Liar
}

\author{
JØRGEN VEISLAND
}

\begin{abstract}
Seduction plays a dual role in Martin A. Hansen's novel The Liar. Johannes Vig, the narrator/protagonist is prone to repeat a pattern of triangular erotic relationships while at the same time engaging in literary seduction. He hides and reveals the truth through a rhetoric of fiction that carries Kierkegaardian overtones. Johannes who is both teacher and preacher on an island off the mainland at some points approximates the Kierkegaardian category of the demonic, being afraid of opening up. Johannes is suffering from a Freudian compulsion to repeat threatening to bar him from the ethical metamorphosis that would absolve him. The repetitiveness of his sexuality paradoxically spurs on a search for truth and ethics as Johannes distances himself from the past in an attempt to transcend the barriers of dualism implicit in the past-present dichotomy. Fictional seduction and rhetorical persuasion become ways of approximating the truth. Yet fiction is abandoned in the end in favour of a different form of writing as Johannes realizes that a new writing project is necessary whereby ethics becomes understood as selflessness. This insight paves the way for the recognition of nature as flux and the recognition of truth as something that cannot be pinned down since it is fundamentally unsubstantial, in the Buddhist sense of sunyata.
\end{abstract}

Keywords: erotic triangles; repetition; dualism; writing as ethics; sunyata

\section{Introduction on the author}

The Danish author Martin A. Hansen (1905-1955) was active in the resistance movement during the Second World War and his work during the war was essential in forming the humanism, the ethics and the Christian perspective on life, society and human relations that characterize his comprehensive literary and scientific work as a prolific author of novels and short stories, and as the author of a major cultural history of Scandinavia and Norse mythology. Hansen's collections of short stories, Tornebusken and Agerhønen, as well as his most important novels, Løgneren and Lykkelige Kristoffer, all published during the first decade after the war, are literary manifestations of the author's major concerns, attitudes and values, and of his approach to literary form. He regarded naturalism and Marxism as limited in their respective views of the social and 
human condition and sought to replace those views with an active Christian humanism and an approach to aesthetics that was both classical and modernist in its emphasis on universal ethical dilemmas unfolded in the individual, subjective mind as well as in the social world.

\section{Recollection and liberation}

The existential and cultural significance of mnemosyne, re-creative recollection, emerges as the central motif in Martin A. Hansen's novel Logneren (The Liar, 1950). Recollection is connected with liberation from time itself, i.e. time in the sense of the limited temporality of personal and societal history. The dialectical philosophy of Søren Kierkegaard and Herbert Marcuse will be especially useful in elucidating how exactly this liberation occurs in Hansen's first-person diary-form narrative, as will indeed certain strands of Buddhist philosophy, particularly the emphases on the way things are, dharma, i.e. continuous change and transience, and on non-substantiality, sunyata.

The implementation of a liberating form of recollection, the remembrance of a temps perdu, may produce social liberation as a revolution of historical forms and political processes. Sigmund Freud's reality principle that operates in opposition to the pleasure principle is not a mental reflection of a universal social condition. Rather, it is a reflection of historicity, of concrete socioeconomic, political restrictions and repressions that function as barriers against pleasure and self-fulfilment. These barriers prompted Kierkegaard to conceive of the subjective absolute, which is the ultimate reflection in the $19^{\text {th }}$-century class society of the recollection of a pre-historic happiness. For Kierkegaard, the concept of repetition, gjentagelse, transcendental continuity, served a therapeutic, epistemological, and even political role. Through understanding repetition, the individual would become liberated from her/his state of demonic un-freedom and from an acute fear of self-revelation and cognition. In Freud's psychology, or metapsychology, however, the liberating potential of repetition and recollection is inverted as it turns into a compulsion to repeat, which basically amounts to a negative submission in the individual to the reality principle. Oppressive social mechanisms are injected into the mind where they work as repression.

In his work Eros and Civilization Herbert Marcuse extrapolates from Freud's theory by a duplication of concepts, arriving at two new terms: "surplusrepression", restrictions effectuated by social domination, and "performance principle" (Marcuse 1966: 35), the local historical form of the reality principle. Because of social repression the cultural force of Eros is obstructed, preventing the creation of communal ties. Arguing that Freud's pleasure principle is 
distorted as "the various objects of the partial instincts" are unified "into one libidinal object", Marcuse comments that this process "achieves the socially necessary de-sexualization of the body" as "the libido becomes concentrated in one part of the body, leaving most of the rest free for use as the instrument of labor." (Marcuse 1966: 48). I would say that Kierkegaard's demonic personality, confined in un-freedom, undergoes precisely this form of de-sexualization, thus turning rebellion into an impotent response to social domination and to the domination of the super-ego. The other side of Eros is Eros unrepressed, Eros as liberation from time, as "timelessness is the ideal of pleasure" (Marcuse 1966: 231), as Marcuse says. If the human instincts were to achieve fulfilment in a nonrepressive social order, Freud's compulsion to repeat would lose its biological rationale, and Eros would be emancipated from time, appearing as a concrete Utopia.

Instinct as Eros and reason as consciousness, mind, co-operate in the human drive to transcend the continuum of history. Kierkegaard's view of time substantiates the integration of instinct and reason since spirit comes about as the fusion of the physical and the intellectual. The positing of spirit is the creation of the moment, øjeblikket, literally the wink of an eye. This concept is also tied to Kierkegaard's definition of being and non-being, truth and illusion. The moment can be the momentary, temporal sensuality and pure aesthetic enjoyment. Or, as the intersection of time and eternity, the moment may reveal truth and being, thus becoming the timelessness of desire, in Kierkegaard's phrase, the fullness of time. When human-ness is suppressed it becomes the purpose of art, literature and philosophy to reproduce the truth that was suppressed by negating that which is. The process of dialectical negativity is therefore the other side or dimension of aesthetics, the ethical dimension. In The Concept of Anxiety (Begrebet Angest; 1843) Kierkegaard writes:

If the moment is posited but merely as discrimen (division), then the future is the eternal. If the moment is posited, so is the eternal, but also the future, which reappears as the past. This is clearly seen in the Greek, the Jewish, and the Christian views. The pivotal concept in Christianity, that which made all things new, is the fullness of time, but the fullness of time is the moment as the eternal, and yet this eternal is also the future and the past. (Kierkegaard 1843/1980: 90)

Further, the moment is an instantaneous, immediate - in the sense of unmediated - experience or recognition. It follows that the moment, occurring in a wink of the eye, is conceived by Kierkegaard as a unique form of timelessness. Kierkegaard's conception, and along with it Heraclitus' idea of simultaneous- 
ness - here I have in mind the expanded river metaphor where it is impossible to "touch mortal substance twice in the same condition", for by "the speed of its change, it scatters and collects again - or rather, it is not again and later but simultaneously that it comes together and departs, approaches and retires" (Barnes 2001: 70), forms a bridge to Buddhist thought as we find it in the Mahamudra, The Great Seal. The Mahamudra signifies the enlightenment of the mind where the ego is non-existing and where mind's own clarity is immediacy. The clue to enlightenment is exactly this experience of immediacy which erases the self and which understands dharma, the way things are, as existing in continuous flux and change; and which, finally, understands mind as the mirror that only reflects fleeting phenomena. Mind's mirror is the momentary timelessness that has no substance, the ultimate non-substance, sunyata, and therefore clear. Verse 10 of the Mahamudra states that "Mind's self-expression, which has never existed as such, is mistaken for an object. / Due to ignorance, self-awareness is mistaken for an 'I'." (Nydahl 2004: 83). Buddhist thought conceives of a limitless openness, an emptiness that permits all forms to arise in the mirror. Emptiness, moreover, paves the way to seeing all things as existing and yet not existing, and this points to another key concept in Kierkegaard's philosophy, the idea of a being-between. Unfortunately, the English translation does not capture Kierkegaard's brilliant pun. The original Danish word here is mellemverende, which means both being-between and having an ethical involvement with existence.

Kierkegaard's being-between and the infinite emptiness conceived by Buddhist thought create a higher ethical sense. Since everything is open and since beings have no concrete substance, a measureless compassion with all living things ensues. It is this compassion the narrator-protagonist of Hansen's novel has to find in himself. Here the temporal dimension becomes pivotal. The narrator constructs a diary, using the first person throughout, but deceives the reader in claiming the diary reports events as they are taking place, whereas in fact everything was written down a year later. Hence the narrator is a liar as his name indicates, Johannes Vig. He admonishes the reader not to pronounce the name too quickly, for that would place the 's' in Johannes in front of the surname Vig, making the word svig, meaning deceit. The narrator's manipulation of time is deliberate and subtle and is performed with a positive intent, that intent being, simply, to uncover the truth indirectly, or to remain within a Kierkegaardian phraseology, to engage in indirect communication. Moreover, as we know from a number of Buddhist philosophers, a.o. Nagarjuna, the truth is not the truth if it does not include lying! 
VEISLAND

\section{Eros and ethics in The Liar}

Johannes has escaped from the mainland to a small island to get away from an erotic triangle. The island is shaped like a whale according to the narrator's own drawing which provides a meticulous topography of the isle, and allusions to Jonah and the whale emerge later in the text. Johannes is teacher at the local schoolhouse and also serves as vicar in the church. The name of the isle is Sandø, a clever pun since the Danish word sand means 'true' and 'sand'. Johannes' diary is a serious experiment in aesthetic and epistemological approximation, whose seemingly deferred aim is to transcend the subject-object and the truth-lie dualism. This is going to be accomplished by a slow revelation of the mind as the truth-state. The revelation is contingent precisely on the playing with time that Johannes engages in while composing the diary; the play with time is a precursor to the erasing of time and the accompanying transformation of time into the limitless space of mind. Therefore, the deceit of the diary is necessary. The temporal delay illustrates and corroborates the illusions of dualism, thus creating the awareness that transcends dualism. Is the island made of sand, fleeting, microscopic grains undergoing continuous change, or is it the topos of truth? It is both, for the two contain one another. The meticulous topography reproduced by Johannes' sketch of the island is a naming of everything, and yet it points to the nameless.

In a conversation with his favourite former student, the young woman Annemari who is engaged to an engineer and with whom Johannes has been in love for a long time, the narrator reveals his deceitful version of the story about his love affair with a woman named Birte on the mainland:

I had to make moral tales, those were my conditions, I'm saying, and didn't I tell you about a certain Birte? Yes, she was my loved one at one time, and then a friend took her away. Later I met them again. And I told you how I withdrew virtuously and left so that nothing would happen between her and me. A fine story.

Well, what did you really do?

You didn't have to reproach me with not obeying the law of love, or whatever it's called. I did that thoroughly. He had taken her from me. All right, I came back and had my revenge. (Hansen 1950: 155-156)

Some years previously Johannes had once again been involved in a triangle, made up of the girl Annemari and her boyfriend at that time, Oluf, both of them Johannes' students at the schoolhouse. Oluf and his brother went out to sea in a small sailing boat even though a storm was brewing, and Johannes did not try to stop them. He now blames himself, suffering pangs of conscience 
as he speculates whether he really wanted Oluf to die drowning. In fact, Oluf managed to save himself but his brother drowned. In Johannes' mind this tragic incident and the guilt associated with it propels the narrative, turning it into a self-examination, initially in the form of a purging and a sexual renunciation which produces a passive kind of moral sense. Johannes has to go further, and this happens when he commences a textual conquest of the island by scientific knowledge, a complete geographical, anthropological, zoological and geological mapping of the history of Sandø. This endeavour changes Johannes from an aesthete, a Kierkegaardian seducer - we have distinct allusions to Kierkegaard's Diary of a Seducer (Forførerens Dagbog; 1843) which formed part of Kierkegaard's Either-Or. Like the Johannes of Kierkegaard's work, Johannes, teacher and preacher, becomes a mediator in a dual sense: a mediator of a new text, and a mediator of love in another person, the woman Rigmor with whom Johannes has a brief but meaningful erotic encounter after Annemari has left with her engineer. This new relationship becomes a selfless friendship where Johannes does not focus on himself but on the other. Further, Johannes engages in charitable work on the island, helping a poor family and inviting a young unmarried mother to live in a vacant apartment attached to the schoolhouse. These actions denote a profound change in the protagonist and are spurred on by a central scene where Johannes, giving a sermon in the church, finds himself possessed by the unclean spirit, Lucifer, or Loke:

Maybe the pride of my own vacant mind, the pride of nothingness itself, has unexpectedly turned into a lust for power. I do not know. But it is as if a mighty, cunning Spirit inhabits me. He makes me much stronger as a man. His mouth curls in a smooth, seductive smile. The people sitting down there have no will of their own any more. Look at the women, they are spellbound. (Hansen 1950: 92-93)

Johannes, the Christian preacher, is possessed by the unclean spirit, Lucifer or Loke, experiencing an acerbated form of nothingness. In Christianity, nothingness is the absolute opposite of the fullness of spirit, a wholeness and a becoming oneself, a state of mind embodied and symbolized by Christ. Like his narrator, the author Hansen is deeply Christian and the text contains a subtext replete with references and citations from the New Testament and the evangelists, including the parable of the unclean spirit and the driving out of the unclean spirit in spring when the snipe, a local bird, appears. Johannes compares himself to the unclean spirit that is exorcised by Christ: 
Maybe I was tempted to say something, dangerously tempted. But what could I truly say about words like these: when the unclean spirit is exorcised from a human soul, he will roam through barren places, seeking rest; and when he does not find it, he says: "I will return to the house I left." What do you think of these words? Do you think the island vicar can even touch such a strange and wild image. The unclean spirit is exiled, banished from his human habitation, dragging his legs through arid deserts, finding nothing to drink, not a dew drop, nor a green blade of grass. Did you imagine the Evil Spirit to be a suffering spirit, Nathanael?

Well, then the desperate unclean Spirit remembers his home, and he returns to it. And when he enters his house, he finds it swept and cleaned. Then he leaves and seeks out seven more Spirits worse than himself, and they all come back to live there; and the end of this human being will be worse than his beginning. (Hansen 1950: 29)

I see the parable as an emblem of the Self and evil as an effect of clinging to the Self, the Ego. The 'house' as ego provides a comfortable, easily recognized home for the Spirit; when driven out by Christ, here the agent of nothingness as a positive emptiness, the unclean Spirit gravitates towards the extreme pole of self assertation. His effort to maintain a self is desperate and results in the augmentation, even radicalization of egoism, the ultimate end of which is a rigid, crystallized self that endeavours to fill up the vacancy produced by the cleaning of the house. The stark poles of fullness and emptiness create a dialectic of dualism not to be transcended.

In Buddhist thought there are no absolute oppositions. Revelation, enlightenment and liberation occur as the effects of the transcendence of dualism. Nothing is either dependent or independent in itself. Everything is inter-dependent as indeed it is in quantum physics. For Johannes to transcend dualism he would have to change his approach to writing. His changing attitude to writing and his starting a new project is initiated, paradoxically, by his experience of nothingness during the sermon. Viewed not from a dialectical perspective but from the point of view of interdependence, nothingness and the "vacant mind" are the negative manifestations of a positive emptiness, a total openness. By extracting the concept of nothingness from a Christian epistemology and inserting it into a Buddhist epistemology, we would attain a transcendence of dualism, thus perceiving, finally, the interdependence of everything and the infinite play of the mind as a mirror where nothing is neither good nor bad in an absolute sense. This insight carries with it a higher ethical sense.

Johannes' new insight is to culminate in a new form of writing that is intimately related to the poetic imagery attached to nature in the novel. 
Particularly significant is the habitat of the snipe which Johannes describes a "wild undergrowth":

The birch woods are not forested, the farmers have had plots there for generations; during the war some trees were felled, but haphazardly so. There is a wild and widespread undergrowth of creeping plants, bushes, small trees, and above it tower some very crooked trees with intertwining branches, covered with fungi and outgrowths. The birch forest is in some places labyrinthine, growing wild, and is enchanting to the wanderer. (Hansen 1950: 30)

The passage is replete with imagery symbolizing a state of unsubstantiality, immanently present in nature, yet manifest in language. Johannes' diary vacillates between the formed and the unformed, thus echoing Sigmund Freud's "Mystic Pad", on which Jacques Derrida comments in "Freud and the Scene of Writing" which forms part of his Writing and Difference. Freud's Mystic Pad is a slab of wax or resin on top of which is fastened a two-layered transparent sheet. The upper part of the sheet is celluloid, the lower part is made of waxed paper. When you write upon the celluloid top sheet the writing is transferred to the waxed paper and then makes an imprint on the wax slab underneath. Derrida pays particular attention to the fact that when the celluloid sheet is lifted, the writing underneath disappears from the bottom sheet but is retained as vague traces on the wax slab. Two hands are needed to manipulate the double sheet, one to lower the sheet and one to raise it again. The traces of the writing appear momentarily only to be erased again. Derrida comments:

Traces thus produce the space of their inscription only by acceding to the period of their erasure. From the beginning, in the "present" of their first impression, they are constituted by the double force of repetition and erasure, legibility and illegibility. (Derrida 1967/2001: 284)

This is a precise description of what Johannes is doing as narrator and protagonist, teacher and preacher or vicar. He manipulates time while writing, activating the dual force of repetition and erasure as performed and illustrated by Freud's writing machine. Through writing, Johannes increasingly distances himself from the past and from repetition, trying to liberate his mind from erotic attachments and compulsions. His intention is to achieve erasure, and this intent is singularly ethical. Writing as an aesthetic endeavour, as creation, is in the foreground in this process; writing may be said to perform the dual, paradoxical function of self-expression and self-erasure. Johannes possesses a dual set of 
VEISLAND

notebooks, consisting of twenty volumes each, one set being filled with notes about the history of the island and its people, the other set blank. The blank notebooks contain limitless potential and possibilities precisely because they are blank. They are to be filled with new notes about the island and its people.

\title{
Abandoning fiction
}

It is significant that Johannes' newly awakened creativity and his choice to abandon the diary in favour of a scientific study of the island coincides with, and indeed propels, a profound change in his character. He changes into a compassionate person as he starts his writing project. He comments as follows on the island:

\begin{abstract}
It was a monster that would swallow human beings and devour generations so that all would be forgotten. Granted, in the daylight it assumes a shape we are familiar with. But it has only acquired this shape by being vanquished by the mind, tied down by language, and by being conquered by the culture that we doubt too much. That is my belief. Every generation must conquer the island. Conquering it is an achievement of the human spirit. Borrowing its beauty is merely parasitic and has nothing to do with spirit. Spirit means ploughing the earth, putting pen to paper in order to win the island through knowledge." (Hansen 1950: 183-184)
\end{abstract}

The new language is a language in process, shifting, always changing as it adapts to the infinitely open shape of the island, tracing its contours as they flicker across the mirror of the mind. Conquering the island means exploring its bottomless depth while recognizing that "all would be forgotten" since everything exists in a continuous state of flux indicative of the unsubstantial, sunyata.

\author{
Jørgen Veisland \\ finjv@univ.gda.pl \\ ul. Wejhera $12 / 2$ \\ 80-346 Gdansk \\ POLSKA / POLAND
}


Eros and Ethics in Martin A. Hansen's Novel The Liar

\section{Bibliography}

\section{Primary sources}

Hansen, M. A. 1950. Løgneren. København: Gyldendal. - Translations into English are mine, J.V.

\section{Secondary sources}

Barnes, J. 1987. Early Greek Philosophy. London: Penguin Books.

Derrida, J. 1967/2001. Writing and Difference. Translated by Alan Bass. London and New York: Routledge Classics.

Freud, S. 1962. Civilization and its Discontents. New York: W.W. Norton \& Company. Kierkegaard, S.1959. Either-Or. Trans. David F. Swenson \& Lilian Marvin Swenson. New York: Anchor Books.

Kierkegaard, S. 1980. The Concept of Anxiety. Trans. Reidar Thomte. Princeton: Princeton University Press.

Kohl, T. C. 2004. Buddhismus und Quantenphysik. Berlin: Windpferd Verlag.

Marcuse, H. 1966. Eros and Civilization. Boston: Beacon Press.

Marcuse, H. 1978. The Aesthetic Dimension. Boston: Beacon Press.

Melberg, A. 1995. Theories of Mimesis. Cambridge: Cambridge University Press.

Nydahl, O. 2004. The Great Seal. The Mahamudra View of Diamond Way Buddhism. San Francisco: Firewheel Publishing. 